\title{
FENOMENA ANOMALI MUSIMAN INDEKS HARGA SAHAM DI INDONESIA
}

\section{G. A. Sri Oktaryani ${ }^{1}$, Iwan Kusuma Negara ${ }^{2}$, Weni Retnowati ${ }^{3}$, Iwan Kusmayadi ${ }^{4}$ \\ 1,2,3,4Faculty of Economics and Business, Mataram University, Indonesia. E-mail: oktaryani@gmail.com}

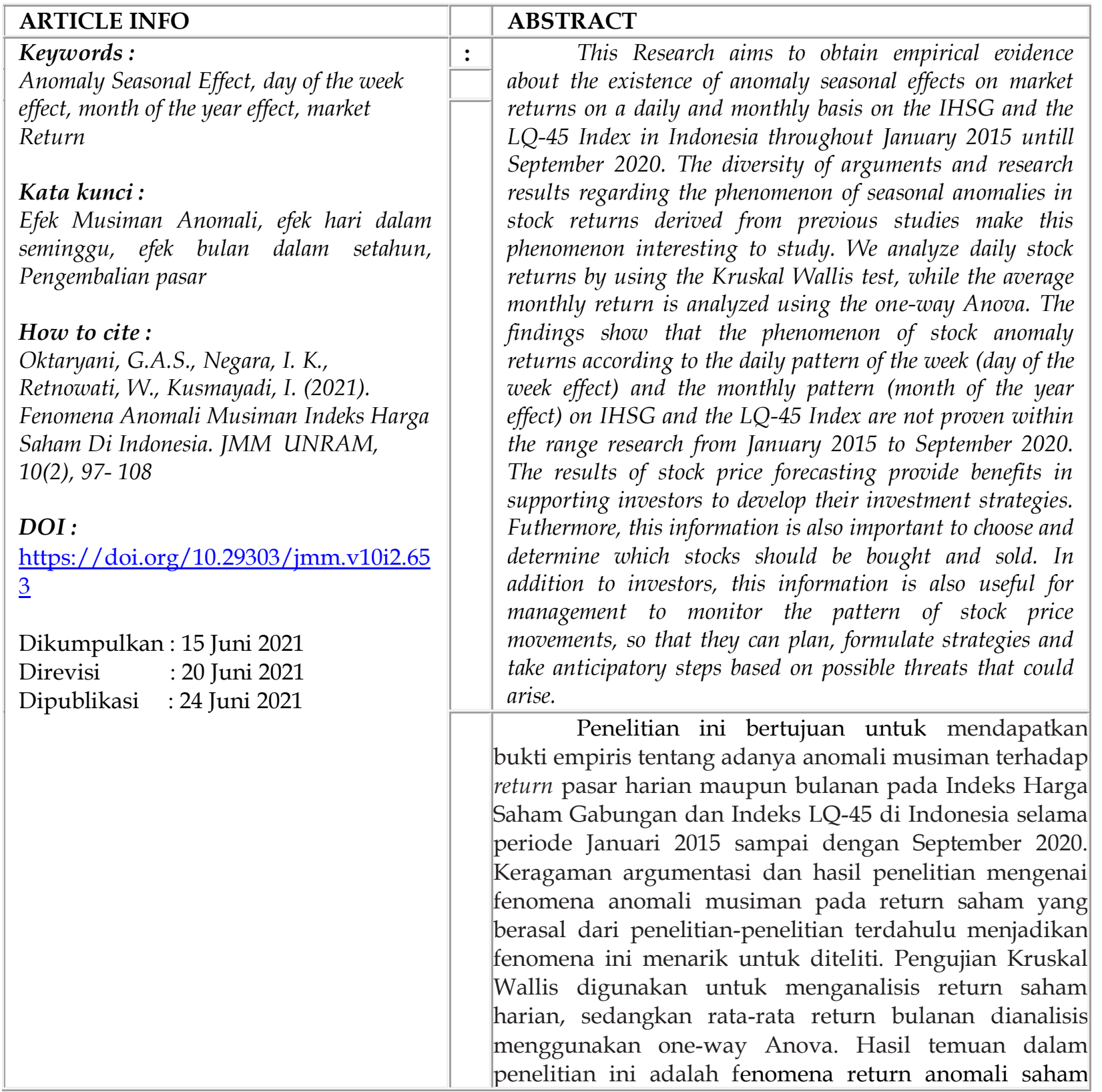




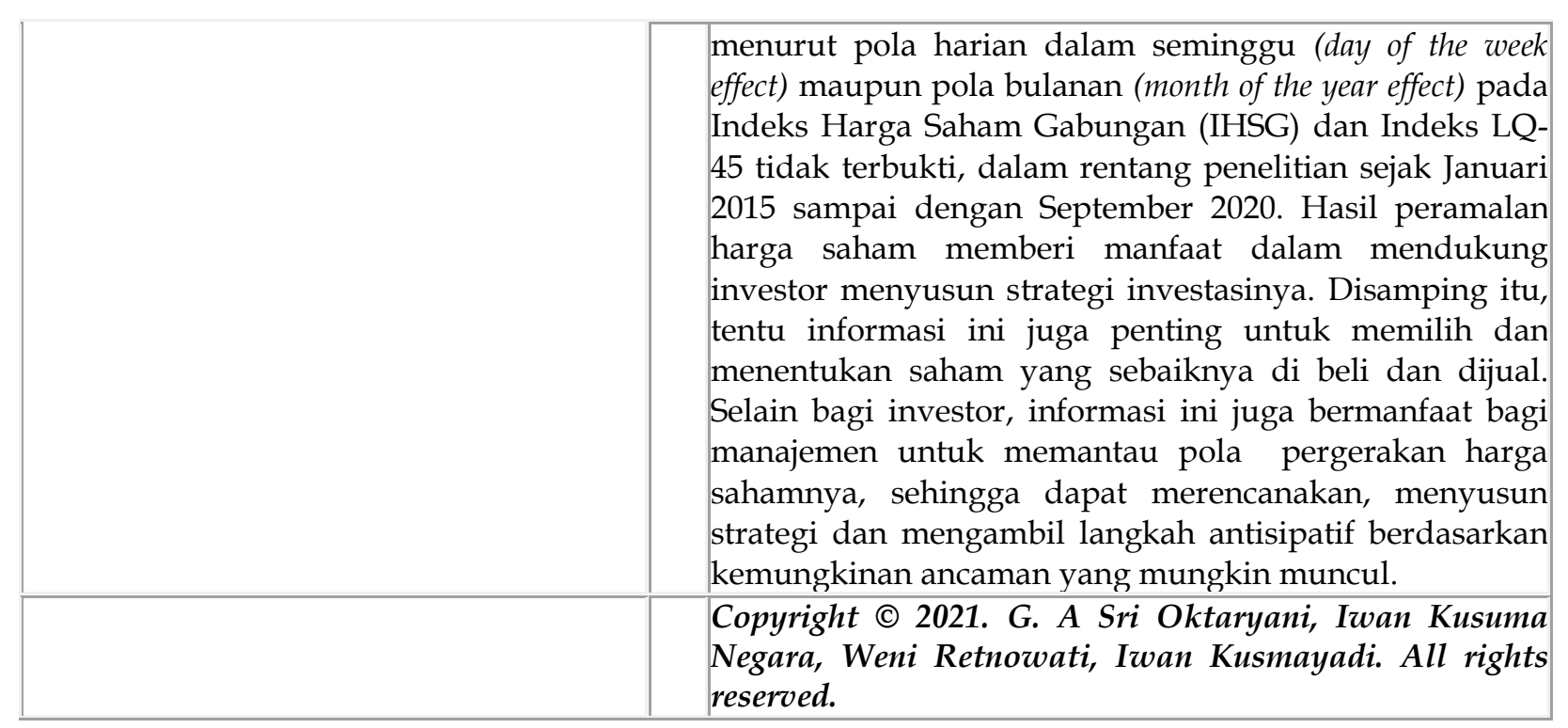

\section{LATAR BELAKANG}

Pengujian pasar efisien tidak bisa terlepas dari membahas tentang adanya ketidakteraturan (anomali) yang terkait dengan hipotesis pasar efisien (Tandelilin, 2001). Pasar efisien merujuk harga sekuritas yang diperdagangkan telah mencerminkan semua informasi yang tersedia. Pasar efisien tercermin dari harga sekuritas merefleksikan informasi yang ada sehingga saham selalu diperdagangkan pada harga yang wajar (Jones, 2002).

Menurut Fama (1970) seperti dikutip dari Hartono (2010), Hipotesis pasar efisien secara informasi dapat diklasifikasikan ke dalam tiga bentuk, yaitu yaitu: (1) Efisien bentuk lemah (weak form); (2) Efisien bentuk setengah kuat (semistrong); (3) Efisien bentuk kuat (strong form). Fama (1991) Pengujian prediktabilitas return (return predictability) merupakan penyempurnaan atas klasifikasi pasar modal efisien, yaitu efisiensi bentuk lemah, dengan melihat pola return dalam anomali pasar. Aga dan Kocaman (2008) juga menemukan adanya efisiensi pasar bentuk lemah di Istanbul Stock Exchange (ISE). Legowo dan Machfoedz (1998) yang telah meneliti pola harga saham di pasar modal di Indonesia tahun 1989 dan 1992 juga menyimpulkan hal yang sama.

Terdapat fenomena lain yang melanggar hipotesis efisiensi pasar bentuk lemah (weak form) karena return yang dihasilkan dari perdagangan tidak random. Jarrett (2010) melakukan pengujian terhadap hipotesis pasar efisien pada small Pacific-basin stock markets. Hasil penemuan menunjukkan bahwa untuk perubahan jangka pendek (harian), pasar empat pasar saham Pasifik memiliki properti yang dapat diprediksi, yang mengarah pada kesimpulan bahwa Efficient Market Hypothesis (EMH) bentuk lemah tidak berlaku untuk pasar yang ditelitinya.

Beberapa penelitian yang dilakukan di beberapa pasar modal di dunia, membuktikan adanya anomali pasar. Salah satunya dilakukan oleh Reinganum \& Saphiro (1987) yang meneliti pada bursa efek London dengan cara membentuk portofolio dari serangkaian saham sebagai proksi dari indeks pasar. Periode penelitian dibagi menjadi sebelum dan sesudah ditetapkannya pajak terhadap capital gain pada tahun 1965.Temuan penelitian tersebut menunjukkan bahwa return saham cenderung tinggi pada bulan Januari dan April pada periode setelah diterapkannya pajak terhadap capital gain. Pola musiman (seasonality effect) ditemukan terjadi di Indonesia. Hasil penelitian Cahyaningdyah (2005) 
dan Kamaludin (2004) mengungkapkan adanya day of the week effect di Bursa Efek Jakarta, dimana return terendah terjadi pada hari Senin (monday effect) dan return tertinggi terjadi pada hari Jumat (weekend effect). Penelitian di lakukan oleh Chang dan Rhee (1994) menemukan penyimpangan dari pengertian pasar yang efisien dalam bentuk lemah. Hasil penelitian ini menunjukkan adanya kecenderungan imbal hasil yang tinggi pada bulan Agustus dan Desember. Sedangkan Ayadi, Dufrene dan Chatterjee (1998) membandingkan pasar modal Ghana, Zimbabwe dan Nigeria, dan berfokus pada periode antara 1985 dan 1995. Menemukan bukti efek Januari hanya di Ghana.

Penelitian di Pasar modal di Yunani yang dilakukan oleh Floros (2008) menunjukkan bahwa tidak ada january effect terhadap return pasar saham di Yunani. Dengan kata lain, pengembalian harian tidak lebih tinggi di bulan Januari daripada di bulan lainnya. Selanjutnya, penelitian yang dilakukan oleh Rossi (2018) tidak menunjukkan bukti kuat Anomali Kalender yang komprehensif.

Berdasarkan riset di atas, maka penelitian ini akan membandingkan dampak pola musiman, yaitu pola harian dan bulanan pada indeks yang berbeda di Bursa Efek Indonesia (BEI) yaitu Indeks Harga Saham Gabungan (IHSG) dan Indeks LQ-45.

\section{KAJIAN PUSTAKA}

\subsection{Pasar Modal Efisien}

Dalam konsep pasar modal yang efisien menurut Fama (1970) yang dikutip dari Hartono (2010), disebutkan ada dua macam pasar efisien yaitu pasar efisien secara informasi, dan pasar efisien secara keputusan. Pasar efisien secara informasi didasarkan pada ketersediaan informasi dimana pasar dikatakan efisien jika pasar bereaksi dengan cepat dan akurat untuk mencapai harga keseimbangan baru yang sepenuhnya mencerminkan informasi yang tersedia. Dengan asumsi bahwa pasar efisien secara informasi, dan bahwa harga dan harapan historis sudah dinilai dalam investasi, maka tidak ada yang dapat melampaui pengembalian rata-rata pasar dengan melihat pada data harga sebelumnya. Sedangkan yang dimaksud dengan pasar efisien secara keputusan ialah bahwa efisiensi pasar juga perlu dilihat berdasarkan kecanggihan pasar dalam mengelola informasi untuk pengambilan keputusan dengan benar. Pasar efisien seperti ini hanya dapat terjadi jika informasi sudah menyebar sempurna, cepat, serta pelaku pasar dapat mengambil keputusan dengan benar (Hartono, 2005).

Pasar efisien tercermin dari harga sekuritas merefleksikan informasi yang ada sehingga saham selalu diperdagangkan pada harga yang wajar (Jones, 2002). Menurut Fama (1970) seperti dikutip dari Hartono (2010) dan Tandelilin (2001), terdapat 3 bentuk utama dari pasar modal yang efisien secara informasi, yaitu: 1) Efisiensi pasar bentuk lemah (weak form eficiency); 2) Efisiensi pasar bentuk pasar setengah kuat (semistrong form eficiency); dan 3) Efisiensi pasar bentuk kuat (strong form). Ketiga bentuk pasar efisien ini berhubungan satu dengan yang lainnya. Nwachukwu dan Shitta (2015) menemukan bahwa perubahan berturut-turut dalam harga saham saling terkait satu sama lain dan karenanya terkandung informasi untuk memprediksi harga di masa depan dalam dua pertiga dari pasar negara berkembang dibandingkan dengan sepertiga dari ekonomi industri. Selain itu efek pergantian tahun kalender terjadi di sebagian dari pasar di negara berkembang dan Sebagian kecil di negara maju. Bila return saham di masa mendatang dapat diprediksi dengan informasi terdahulu, maka dapat dikatakan bahwa pasar modal tersebut tidak efisien.

\subsection{Anomali Pasar Efisien}

jmm.unram.ac.id 
Anomali pasar efisien berarti penyimpangan atau ketidakkonsistenan terhadap hipotesis pasar modal efisien, yang terjadi berulang-ulang, menyimpang secara konsisten dari kondisi pasar yang efisien secara informasi. Jones (2002:329) mendefinisikan anomali pasar efisien sebagai teknik yang bertentangan dengan pasar efisien atau penolakan terhadap pasar efisien, namun hingga saat ini kebanyakan dari jenis anomali tersebut belum dapat dijelaskan penyebabnya.

Menurut Hartono (2005:96) terdapat beberapa anomali yang mendapat banyak perhatian, yaitu: (1) Anomali yang disebabkan karena strategi price earning ratio (PER) rendah (Low P/E Ratio); (2) Anomali akibat efek ukuran perusahaan (size effect) dimana perusahaan kecil yang mampu memberikan imbal hasil yang lebih besar dibandingkan dengan perusahaan besar; (3) Anomali efek jangka Panjang, seperti return jangka panjang negatif untuk initial public offering (IPO) dan imbal hasil jangka panjang positif untuk stock split; dan (4) Anomali efek kalender.

Beberapa penelitian yang terkait dengan anomaly pasar efisien antara lain dilakukan oleh Seyyed, Abraham dan Al-Hajj (2005) menemukan adanya pola penurunan sistematis volatilitas selama Ramadhan di pasar saham Arab Saudi. Anomali ini tampaknya konsisten dengan penurunan aktivitas perdagangan selama bulan Ramadhan., Brusa, Hernandez dan Liu (2011) menemukan adanya anomali musiman (weekend effect) khususnya pada perusahaan-perusahaan besar, dan anomali pada tingkat perusahaan tidak terdistribusi secara merata sepanjang minggu dalam sebulan. Lebih jauh, volume perdagangan dan likuidasi dari masing-masing perusahaan dapat hanya sebagian menjelaskan anomali musiman. Heston dan Sadka (2016) menemukan adanya efek musiman yang persisten dalam return saham. Weigerding dan Hanke (2018) mengidentifikasi likuiditas pasar sebagai pendorong utama musiman return saham di Jerman daripada berita makro ekonomi Amerika Serikat. Lobão (2019), menemukan adanya efek pra-liburan yang sangat signifikan terhadap return, selain itu, efek pergantian bulan, efek bulanan dan hari dalam seminggu efek terdeteksi di beberapa pada American Depository Receipt (ADR). Pola musiman yang dianalisis cenderung lebih kuat di ADR berbasis pasar yang muncul. Sedangkan Hai Yue Liu, et.all, (2020) mengevaluasi dampak jangka pendek dari wabah coronavirus pada 21 saham terkemuka indeks pasar di negaranegara yang terkena dampak utama termasuk Jepang, Korea, Singapura, Amerika Serikat, Jerman, Italia, dan Inggris. Konsekuensi penyakit menular sangat besar dan langsung mempengaruhi pasar saham di seluruh dunia.

\subsection{Pola Return Sekuritas}

Sejumlah penelitian menunjukkan adanya suatu pola dalam return sekuritas. Pola tersebut menunjukkan adanya tingkat imbal hasil yang lebih tinggi atau lebih rendah pada saat tertentu baik dalam periode harian maupun bulanan. Berikut ini ialah uraiannya:

1) Pola harian,

Salah satu pola return secara intensif diteliti adalah adanya perbedaan return untuk hari-hari tertentu dalam seminggu. Gibbons danHess (1981) dalam Tandelilin (2001:116), menemukan adanya return yang negatif pada hari perdagangan senin. Gibbons dan Hess juga menemukan bahwa return yang positif terjadi pada hari perdagangan rabu dan jumat. Harris (1968) dalam Tandelilin (2001:117), melakukan penelitian mengenai pola return dalam satu hari (intraday pattern) dan hari bursa dalam seminggu (day of the week pattern). Harris (1968) menemukan juga bahwa pada hari senin terdapat return yang negatif tetapi pada empat hari lainnya returnnya positif. Return yang negatif di hari senin tidak terjadi sepanjang hari tetapi setengahnya terjadi pada saat penutupan pasar di hari jumat dan pembukaan pasar di 
hari senin. Setelah pembukaan pasar di hari senin, return di hari senin akan sama dengan hari-hari lainnya. Harris juga menemukan bahwa setiap hari terjadi kenaikan harga pada 30 menit terakhir perdagangan. Perlu diperhatikan bahwa penelitian ini hanya mengamati data dalam waktu yang singkat dan pasar mungkin sudah menyesuaikan pola tersebut, sehingga strategi dengan tersebut tidak akan berhasil mendapatkan abnormal return yang diharapkan.

2) Pola Bulanan

Fama (1991) dalam Tandelilin (2001:117), menemukan bahwa pada periode 1941 sampai dengan 1981, return di bulan januari lebih tinggi dibandingkan bulan-bulan lainnya. Selama periode 1982 sampai dengan januari 1991, Fama juga menemukan hal yang sama, tetapi perbedaan imbal hasil di bulan januari untuk saham kecil maupun saham besar namun tidak terlalu besar.

Al-Saad dan Moosa (2005) menemukan efek bulan Juli (efek liburan musim panas), kecenderungan para pengelola dana yang melepas posisi investasi jangka pendek untuk liburan musim panas. Sedangkan Compton, Johnson dan Kunkel (2006) menemukan terjadinya turn-of-the-month (TOM) effect terhadap return bulanan di lima indeks REIT domestik.

Iramani dan Mahdi (2006) menyebutkan beberapa penelitian yang dilakukan di Bursa Efek Indonesia menyimpulkan bahwa return pada bulan April lebih tinggi dibandingkan bulan lainnya atau lebih dikenal dengan sebutan April effect.

\section{METODE PENELITIAN}

\subsection{Jenis Penelitian}

Penelitian ini merupakan penelitian komparatif, yang bertujuan untuk membandingkan return saham harian dan bulanan pada Indeks IHSG dan LQ-45 dengan menggunakan uji beda untuk membuktikan gejala anomaly return saham harian (the day of the week effect) dan bulanan (month of the year effect) pada kelompok perusahaan yang tergabung dalam Indeks Harga Saham Gabungan (IHSG) dan Indeks LQ-45.

\subsection{Populasi dan Sampel}

Populasi penelitian ini adalah indeks saham yang terdapat di Bursa Efek Indonesia (BEI). Saat ini terdapat 35 indeks saham di BEI. Sampel yang ditentukan dalam penelitian ini menggunakan dua indeks yaitu Indeks Harga Sahama gabungan (IHSG) dan Indeks LQ-45 dalam kurun waktu Januari 2015 sampai dengan September 2020. IHSG merepresentasikan kinerja harga semua saham yang tercatat di papan utama dan papan pengembangan BEI, sedangkan Indeks LQ-45 adalah cerminan dari saham perusahaan dengan likuiditas, kapitalisasi dan kinerja fundamental yang baik.

\subsection{Jenis dan Sumber Data}

Data dalam penelitian ini merupakan data-data kuantitatif yang bersumber dari data sekunder yang dikumpulkan melalui dokumentasi dari situs website yang relevan yaitu idx.co.id dan finance.yahoo.com berupa data time series harga saham harian dan bulanan dari IHSG dan Indeks LQ-45.

\subsection{Variabel Penelitian}

a) Return saham harian dari IHSG dan Indeks $L Q-45$

b) Return saham bulanan dari IHSG dan LQ-45

\subsection{Prosedur Analisis Data}

jmm.unram.ac.id 
Prosedur analisis data dalam penelitian ini adalah sebagai berikut:

a) Menentukan Return harian dari masing-masing Indeks (IHSG dan LQ 45) selama periode Januari 2015 sampai dengan September 2020 yang dihitung menggunakan harga penutupan (closing price)

Perhitungan Return adalah sebagai berikut (Hartono, 2010):

$$
R_{i t}=\frac{P_{i t}-P_{i t-1}}{P_{i t-1}}
$$

Keterangan:

$$
\begin{aligned}
& R_{i t} \quad=\text { Return actual } \\
& P_{i t} \quad=\text { closing price pada hari/bulan ke } t \\
& P_{i t-1}=\text { closing price pada harike } t-1 / \text { bulan ke } t-1
\end{aligned}
$$

b) Mengelompokkan return indeks (IHSG dan LQ-45) menurut hari (senin sampai hari jumat) sesuai hari perdagangan aktif sejak Januari 2015 sampai dengan September 2020.

c) Menetukan rata-rata return bulanan pada setiap indeks (bulan Januari sampai dengan Desember) selama periode penelitian dengan perhitungan sebagai berikut:

$$
\check{R} \quad=\frac{\sum R_{1}+R_{2}+R_{3}+\ldots R_{n}}{N}
$$

Keterangan :

$\mathrm{N}$ : banyaknya sampel

d) Analisis Deskriptif

Statistik deskriptif memberi gambaran atau deskripsi suatu data yang dilihat dari nilai rata-rata (mean), standar deviasi, maksimum, minimum, dan range (Ghozali, 2012). Statistik deskriftif memberikan gambaran tentang nilai rata-rata (mean), standard deviasi, varian, nilai maksimum dan minimm. Range, sum, kurtosis dan skewness (kemencengan distribusi) dari data.

e) Pengujian Normalitas data

Uji Normalitas data dalam penelitian ini menggunakan One Sample Kolmogorov -Smirnov Test, salah satu metode statistic paramtrik. Data memiliki distribusi normal jika nilai assymtotic significance $>$ nilai alpha $=0,05$. Namun jika data tida $\mathrm{k}$ memiliki distribusi normal, maka metode analisis statistic menggunakan statistic non-parametrik, menggunakan Kruskal Wallis.

f) Pengujian kesamaan variansi populasi (Test of Homogeneity of variances)

Pengujian homogenitas dilakukan sebagai syarat dalam analisis komparatif seperti uji independent sample $t$ test dan uji ANOVA. Pengujian ini bertujuan untuk mengetahui apakah variasi beberapa data dari populasi memiliki varians yang sama atau tidak. Tahap ini perlu dilakukan karena sebagai bahan acuan untuk menentukan keputusan uji statistik berikutnya. Dasar pengambilan keputusan dalam uji homogenitas adalah sebagai berikut:

Jika nilai signifikansi lebih kecil dari 0,05, maka dikatakan varian dari dua atau lebih kelompok populasi data adalah tidak sama atau tidak homogen, dan sebaliknya.

g) Pengujian Hipotesis

Bila data berdistribusi Normal dan Variansnya adalah sama, maka pengujian hipotesis dilakukan dengan One Way Anova untuk mengetahui perbedaan rata-rata return indeks dalam harian. Namun jika data berdistribusi tidak normal, maka pengujian hipotesis menggunakan metode statistic non-parametrik Kruskal Wallis untuk mengetahui 
perbedaan rata-rata return dari indeks (IHSG dan LQ-45) dalam harian maupun bulanan.

1) Menetukan formulasi hipotesis

Hipotesis 1 :

Rumusan dalan uji hipotesis adalah sebagai berikut:

$\mathrm{H}_{01}$ : Tidak ada perbedaan rata-rata return indeks harian (dalam lima hari perdagangan saham.

$\left(\mu_{\text {Senin }}=\mu_{\text {Selasa }}=\mu_{\text {Rabu }}=\mu_{\text {Kamis }}=\mu_{\text {Jumat }}\right)$

$\mathrm{H}_{\mathrm{A} 1}$ : Ada perbedaan rata-rata return saham harian dalam lima hari perdagangan saham.

Hipotesis 2 : $\left(\mu_{\mathrm{i}} \neq \mu_{\mathrm{j}} ;\right.$ untuk $\left.\mathrm{i} \neq \mathrm{j}\right)$

Rumusan dalan uji hipotesis adalah sebagai berikut :

$\mathrm{H}_{02}$ : Tidak ada perbedaan rata-rata return indeks bulanan (dalam 12 bulan.

$\left(\mu_{\text {Januari }}=\mu_{\text {Februari }}=\mu_{\text {maret }}=\mu_{\text {April }}=\mu_{\text {Mei }}=\mu_{\text {Juni }}=\mu_{\text {Juli }}=\mu_{\text {Agustus }}=\mu_{\text {September }}=\right.$ $\left.\mu_{\text {Oktober }}=\mu_{\text {November }}=\mu_{\text {Desember }}\right)$

$\mathrm{H}_{\mathrm{A} 1}$ : Ada perbedaan rata-rata return indeks bulanan (dalam 12 bulan $\left(\mu_{\mathrm{i}} \neq \mu_{\mathrm{j}} ;\right.$ untuk $\left.\mathrm{i} \neq \mathrm{j}\right)$

2) Menetukan tingkat signifikansi

Dengan taraf keyakinan 95\% dengan tingkat signifikansi, $a=5 \%$.

3) Menentukan kriteria pengujian dan pengambilan keputusan

Kriteria pengujian hipotesis metode ANOVA adalah:

$\mathrm{H}_{01}$ Ditolak jika hasil p-value (sig) $<5 \%$

$\mathrm{H}_{01}$ Diterima jika hasil $p$-value (sig) $\geq 5 \%$

4) Menarik Kesimpulan:

- Membuktikan day of the week effect:

$\mathrm{H}_{01}$ Ditolak jika hasil $p$-value (sig) $<5 \%$, dapat disimpulkan bahwa ada perbedaan rata-rata return saham harian dalam lima hari perdagangan saham (terjadi day of the week effect), namun bila hasil p-value (sig) $\geq 5 \%$, maka $\mathrm{H}_{01}$ Diterima atau $\mathrm{H}_{\mathrm{A} 1}$ Ditolak, dapat disimpulkan bahwa tidak ada perbedaan rata-rata return saham harian dalam lima hari perdagangan (Tidak terjadi day of the week effect).

- Membuktikan month of the year effect :

$\mathrm{H}_{01}$ Ditolak jika hasil $p$-value (sig) $<5 \%$, dapat disimpulkan bahwa ada perbedaan rata-rata return saham bulanan dalam 12 bulan (terjadi day of the week effect), namun bila hasil p-value (sig) $\geq 5 \%$, maka $\mathrm{H}_{01}$ Diterima atau $\mathrm{H}_{\mathrm{A} 1}$ Ditolak, dapat disimpulkan bahwa tidak ada perbedaan rata-rata return saham bulanan dalam 12 bulan perdagangan (Tidak terjadi month of the year effect). 


\section{HASIL DAN PEMBAHASAN}

\subsection{Analisis data}

Data-data yang dikumpulkan adalah harga penutupan dari masing-masing indeks yaitu Index Harga Saham Gabungan (IHSG) dan Index LQ-45 dalam harian sejak awal perdagangan pada bulan Januari 2015 sampai dengan bulan September 2020.

Tabel 4.1

Transaksi perdagangan harian sejak Tahun 2015 - September 2020

\begin{tabular}{cc} 
Hari & $\begin{array}{c}\text { Jumlah transaksi aktif } \\
(\text { kali) }\end{array}$ \\
\hline Senin & 280 \\
Selasa & 283 \\
Rabu & 284 \\
Kamis & 279 \\
Jumat & 278 \\
\hline Jumlah & $\mathbf{1 . 4 0 3}$
\end{tabular}

Sumber: data sekunder diolah

Berdasarkan data yang ditunjukkan dalam tabel di atas, jumlah transaksi aktif harian sebanyak 1403 transaksi pada masing-masing indeks yaitu IHSG dan LQ-45, dimana jumlah transaksi perdagangan harian tertinggi terjadi pada hari Rabu yaitu sebanyak 284 transaksi dan jumlah paling sedikit terjadi pada hari Jumat yaitu sebanyak 278 transaksi,

Menurut perkembangan harga saham pada IHSG dan ILQ 45 sejak Januari 2015 sampai bualn September 2020 adalah dimana Indeks harga tertinggi untuk IHSG adalah senilai Rp 6.689,29 yaitu pada hari Senin tanggal 19 Februari 2018. Sedangkan terendah terjadi pada hari Selasa tanggal 24 Maret 2020 yaitu seharga Rp 3.937,63. Rata-rata harga indeks IHSG dari 1.403 hari perdagangan aktif sejak Januari sampai September 2020 adalah sebesar Rp 5.548,21. Sementara untuk harga Indeks LQ 45, harga tertinggi mencapai Rp 1.132,19 pada hari Selasa tanggal 23 Januari 2018 dan terendah sebesar Rp 566,83 pada hari Selasa tanggal 24 Maret 2020, dengan harga rata-rata sebesar Rp 911,67. Penjelasan perbandingan harga dan return pada IHSG dan Indeks LQ dapat ditunjukkan dalam tabel di bawah ini:

Tabel 4.2

Harga dan Return Saham IHSG dan LQ-45 Tahun 2015 - 2020 Descriptive Statistics

\begin{tabular}{|l|c|r|r|r|r|r|}
\hline & $\mathrm{N}$ & $\begin{array}{c}\text { Minimu } \\
\mathrm{m}\end{array}$ & Maximum & Mean & $\begin{array}{c}\text { Std. } \\
\text { Deviation }\end{array}$ & Variance \\
\hline $\begin{array}{l}\text { Harga } \\
\text { Penutupan } \\
\text { IHSG }\end{array}$ & 1403 & $3,937.63$ & $6,689.29$ & $5,548.212$ & 637.58019 & 406508.498 \\
Harga & 1403 & 566.83 & $1,132.19$ & 911.6758 & 97.66024 & 9537.522 \\
$\begin{array}{l}\text { Penutupan } \\
\text { ILQ45 }\end{array}$ & & & & & \\
$\begin{array}{l}\text { Return IHSG } \\
\text { Return ILQ45 }\end{array}$ & 1403 & -.0658 & .1019 & .000028 & .0104921 & .000 \\
$\begin{array}{l}\text { Valid N } \\
\text { (listwise) }\end{array}$ & 1403 & -.0826 & .1492 & -.000013 & .0139329 & .000 \\
\hline
\end{tabular}

Sumber: data sekunder diolah

Kemudian informasi returns IHSG dan LQ-45 sejak 2015 sampai dengan September 2020, dimana return dari indeks saham IHSG maksimum sebesar 0,1019 yaitu 
pada hari Kamis tanggal 26 Maret 2020, sedangkan return terendah yang dimiliki oleh IHSG adalah sebesar -0,068 yang terjadi pada hari Senin tanggal 09 Maret 2020. Sedangkan pada indeks LQ-45 return tertinggi tercapai pada 0,1492 pada hari Kamis tanggal 26 Maret 2020, sedangkan terendah pada hari Senin tanggal 09 Maret 2020 yaitu sebesar 0,0826. Ratarata return IHSG harian adalah sebesar 0,000028 , sedangkan return rata-rata pada indeks LQ-45 adalah sebesar -0,000013.

\section{Hasil Uji Normalitas Data}

Uji Normalitas data dalam penelitian ini menggunakan One Sample Kolmogorov Smirnov Test. Data memiliki distribusi normal jika nilai assymtotic significance $>$ nilai alpha $=0,05$. Pada Tabel 4.3 berikut adalah hasil uji normalitas dengan menggunakan K-S test untuk return harian IHSG dan LQ-45.

Tabel 4.3

Uji Normalitas data Return Harian dengan Kolmogorov-Smirnov Test Tests of Normality

\begin{tabular}{|c|c|c|c|c|c|c|c|c|}
\hline & \multirow{2}{*}{\multicolumn{2}{|c|}{$\begin{array}{l}\text { Hari } \\
\text { Perdagangan }\end{array}$}} & \multicolumn{3}{|c|}{ Kolmogorov-Smirnova } & \multicolumn{3}{|c|}{ Shapiro-Wilk } \\
\hline & & & Statistic & $\mathrm{df}$ & Sig. & $\begin{array}{c}\text { Statisti } \\
\mathrm{c}\end{array}$ & $\mathrm{df}$ & Sig. \\
\hline \multirow{5}{*}{$\begin{array}{l}\text { Return } \\
\text { Harian } \\
\text { IHSG }\end{array}$} & \multirow{5}{*}{$\begin{array}{c}\text { dimens } \\
\text { ion1 }\end{array}$} & Senin & .067 & 280 & .004 & .949 & 280 & .000 \\
\hline & & Selasa & .102 & 283 & .000 & .817 & 283 & .000 \\
\hline & & Rabu & .090 & 284 & .000 & .913 & 284 & .000 \\
\hline & & Kamis & .094 & 279 & .000 & .929 & 279 & .000 \\
\hline & & Jumat & .113 & 278 & .000 & .887 & 278 & .000 \\
\hline \multirow{5}{*}{$\begin{array}{l}\text { Return } \\
\text { Harian } \\
\text { LQ45 }\end{array}$} & \multirow{5}{*}{$\begin{array}{c}\text { dimens } \\
\text { ion1 }\end{array}$} & Senin & .073 & 280 & .001 & .952 & 280 & .000 \\
\hline & & Selasa & .112 & 283 & .000 & .782 & 283 & .000 \\
\hline & & Rabu & .084 & 284 & .000 & .929 & 284 & .000 \\
\hline & & Kamis & .093 & 279 & .000 & .923 & 279 & .000 \\
\hline & & Jumat & .106 & 278 & .000 & .891 & 278 & .000 \\
\hline
\end{tabular}

a. Lilliefors Significance Correction

Hasil di atas menunjukkan bahwa data return harian pada IHSG maupun LQ-45 keduanya tidak berdistribusi normal karena nilai signifikansi lebih kecil dari 0,05, maka metode analisis statistic menggunakan statistic non-parametrik, menggunakan Kruskal Wallis.

Sedangkan uji normalitas pada return bulanan IHSG dan LQ-45 ditunjukkan dalam Tabel 4.4 berikut: 
Tabel 4.4

Uji Normalitas data Return Bulanan dengan Kolmogorov-Smirnov Test

Tests of Normality

\begin{tabular}{|c|c|c|c|c|c|c|c|c|}
\hline & Bulan Perda & gangan & $\begin{array}{r}\text { Kolm } \\
\text { Sm }\end{array}$ & $\begin{array}{l}\text { ogor } \\
\text { rno }\end{array}$ & & Shapi & co- $V$ & \\
\hline & & & $\begin{array}{c}\text { Statisti } \\
\text { C }\end{array}$ & Df & Sig. & $\begin{array}{c}\text { Statisti } \\
\text { C }\end{array}$ & $\mathrm{df}$ & Sig. \\
\hline Rata- & & Januari & .257 & 6 & $.200^{*}$ & .916 & 6 & .478 \\
\hline rata & & Februari & .232 & 6 & $.200^{*}$ & .843 & 6 & .139 \\
\hline Return & & Maret & .328 & 6 & .042 & .791 & 6 & .049 \\
\hline Bulanan & & April & .218 & 6 & $.200^{*}$ & .948 & 6 & .720 \\
\hline & & Mei & 180 & 6 & $.200^{*}$ & .938 & 6 & .646 \\
\hline & dimoncinn1 & Juni & .325 & 6 & .047 & .780 & 6 & .039 \\
\hline & amensiont & Juli & .185 & 6 & $.200^{*}$ & .937 & 6 & .639 \\
\hline & & Agustus & .238 & 6 & $.200^{*}$ & .843 & 6 & .139 \\
\hline & & September & 299 & 6 & 100 & .812 & 6 & .076 \\
\hline & & Oktober & .330 & 5 & .079 & .800 & 5 & .082 \\
\hline & & November & .173 & 5 & $.200^{*}$ & .961 & 5 & .816 \\
\hline & & Desember & .240 & 5 & $.200^{*}$ & .905 & 5 & .436 \\
\hline Rata- & & Januari & .222 & 6 & $.200^{*}$ & .925 & 6 & .544 \\
\hline & & Februari & .167 & 6 & $.200^{*}$ & .925 & 6 & .540 \\
\hline Return & & Maret & .423 & 6 & .001 & .639 & 6 & .001 \\
\hline Butanan & & April & .213 & 6 & $.200^{*}$ & .944 & 6 & .692 \\
\hline & & Mei & .123 & 6 & $.200^{*}$ & .997 & 6 & .999 \\
\hline & dimencion 1 & Juni & .360 & 6 & .015 & .712 & 6 & .008 \\
\hline & & Juli & 172 & 6 & $.200^{*}$ & .938 & 6 & .642 \\
\hline & & Agustus & .228 & 6 & $.200^{*}$ & .915 & 6 & .471 \\
\hline & & September & .294 & 6 & .114 & .745 & 6 & .018 \\
\hline & & Oktober & .323 & 5 & .097 & .878 & 5 & .302 \\
\hline & & November & 199 & 5 & $.200^{*}$ & .976 & 5 & .910 \\
\hline & & Desember & . 160 & 5 & $.200^{*}$ & .975 & 5 & .906 \\
\hline
\end{tabular}

a. Lilliefors Significance Correction

*. This is a lower bound of the true significance.

Menurut tabel $4.4 \mathrm{di}$ atas, data rata-rata return bulanan pada IHSG dan LQ-45 berdistribusi normal karena nilai sig $>0,05$, kecuali bulan Maret dan Juni diketahui tidak berdistribusi normal, maka pengujian hipotesis dilakukan dengan One Way Anova untuk mengetahui perbedaan rata-rata return indeks dalam bulanan IHSG dan LQ-45.

Sebelum pengujian hipotesis, data yang berdistribusi normal perlu di uji homogenitas. Pengujian homogenitas dilakukan sebagai syarat dalam analisis komparatif seperti uji independent sample $t$ test dan uji ANOVA. Pengujian ini dilakukan untuk mengetahui variasi beberapa data dari populasi. Tahap ini perlu dilakukan karena sebagai bahan acuan untuk menentukan keputusan uji statistik berikutnya. 
Tabel 4.5 Uji Homogenitas

Rata return bulanan IHSG dan LQ-45 Tahun 2015 sampai dengan September 2020

Test of Homogeneity of Variances

\begin{tabular}{|l|r|r|r|r|}
\hline & $\begin{array}{r}\text { Levene } \\
\text { Statistic }\end{array}$ & \multicolumn{1}{c|}{ df1 } & \multicolumn{1}{c|}{ df2 } & \multicolumn{1}{c|}{ Sig. } \\
\hline $\begin{array}{l}\text { Rata-rata Return } \\
\text { Bulanan_IHSG } \\
\begin{array}{l}\text { Rata-rata Return Bulanan } \\
\text { LQ45 }\end{array}\end{array}$ & 1.789 & 11 & 57 & .077 \\
\hline
\end{tabular}

Pada tabel 4.5 diatas adalah hasil pengujian homogenitas terhadap rata-rata return bulanan IHSG dan LQ-45 Tahun 2015 sampai dengan September 2020. Berdasarkan tebel 4.5 di atas karena nilai signifikansi rata-rata return bulanan IHSG dan LQ 45 masingmasing adalah sebesar 0,077 dan 0,499 atau sig. > 0,05, maka dikatakan varian dari dua atau lebih kelompok populasi data tersebut adalah sama atau homogen.

\section{KESIMPULAN DAN SARAN}

Hasil kajian ini menyimpulkan bahwa fenomena return anomaly saham menurut pola harian dalam seminggu (day of the week effect) maupun secara bulanan (month of the year effect) pada Indeks Harga Saham Gabungan (IHSG) dan Indeks LQ 45 tidak terbukti, dalam rentang penelitian sejak Januari 2015 sampai dengan September 2020. Hasil penelitian ini selaras dengan penelitian Ali dan Ülkü (2020), Rossi (2018) dan Floros (2008). Dengan segala kekurangan dan keterbatasan dalam penelitian ini, maka perlu dilakukan pengujian dengan menambahkan variabel lain untuk melihat perbedaan return, dengan rentang waktu yang lebih lama dan terkini, perbandingan untuk beberapa indeks yang lebih beragam, serta perbandingan corporate action seperti pembagian dividen, size effect, akuisisi.

\section{DAFTAR PUSTAKA}

Aga, M \& Kocaman, B. (2011). Efficient Market Hypothesis and Emerging Capital Markets: Empirical Evidence from Istanbul Stock Exchange. Journal of Financial Markets Research, Issue 3, 44-57

Ali, F. \& Ülkü, N. (2020). Weekday Seasonality of Stock Returns: The Contrary Case of China. Journal of Asian Economics, 68, 1-15. https://doi.org/10.1016/j.asieco.2020.101201

Al-Saad, K. \& Moosa, I. A. (2005). Seasonality in stock returns: evidence from an emerging market. Applied Financial Economics, 15(1), 63-71.

Ayadi, O. F., Dufrene, U. B. \& Chatterjee, A. (1998). Stock return seasonalities in lowincome African emerging markets. Managerial Finance, Vol. 24(3), 22 - 33.

Brusa, J., Hernandez, R. \& Liu, P. (2011). Reverse weekend effect, trading volume, and illiquidity. Managerial Finance, 37(9), 817 - 839

Cahyaningdyah, D. (2005). Analisis Pengaruh Hari Perdagangan Terhadap Return Saham: Pengujian Week Four Effect Dan Rogalski Effect Di Bursa Efek Jakarta.Jurnal Ekonomi danBisnis Indonesia, 20(2), 175-186.

Chang, P. \& Rhee, G. (1994). The Return Behavior of Indonesian Stocks. Working paper, Pacific Basin Finance Journal.

Compton. W. S., Johnson, D. T. \& Kunkel, R. A. (2006). The turn-of-the-month effect in real estate investment trusts (REITs). Managerial Finance, 32(12), 969-980. 
Floros, C. (2008). The monthly and trading month effects in Greek stock market returns: 1996-2002, Managerial Finance, 34(7), 453-464

Ghozali, I. (2012). Aplikasi Analisis Multivariate Dengan Program IBM SPSS 20. Semarang: Badan Penerbit - Undip.

Hartono, J. (2005). Pasar Efisien Secara Keputusan.Jakarta: GramediaPustakaUtama.

Hartono, J. (2010). Teori Portofolio dan Analisis Investasi. Edisi ketujuh. Cetakan Pertama. BPFE-Yogyakarta. Yogyakarta.

Heston, S. L. \& Sadka, R. (2016). Seasonality in the Cross-Section of Stock Returns. Journal of Financial Economics, 8(2), 418-445.

Iramani, R. \& Mahdi, A. (2006). Studi Tentang Pengaruh Hari Perdagangan Terhadap Return Saham pada BEJ. JurnalAkuntansi dan Keuangan, 8(2), 63-70

Jarrett, J. E. (2010). Efficient markets hypothesis and daily variation in small Pacific-basin stock market. Management Research Review, 33(12), 1128 - 1139.

Jones, C. P. (2002). Investment Analysis and Management. Eightedition. USA: John Wiley \& Sons, Inc.

Kamaludin. (2004). Calender And Daily Information Effect InJakarta Stock Exchange. Jurnal Bisnis dan Akuntansi, Th XIV, No.3, 273-292

Liu, H. Y., Manzoor, A., Wang, C. Y., Zhang, L. \& Manzoor, Z. (2020). The COVID-19 Outbreak and A_ected Countries Stock Markets Response. International Journal of Environmental Research and Public Health, 17(8). doi:10.3390/ijerph17082800

Lobão, J. (2019). Seasonal anomalies in the market for American depository receipts. Journal of Economics, Finance and Administrative Science, 24(48), 241-265.

Legowo, H. \& Machfoedz, M. (1998). Efisiensi Pasar Modal: Perbandingan Pada Dua Periode Yang Berbeda Dalam Pasar Modal Indonesia. Jurnal Ekonomi dan Bisnis Indonesia, Vol.13 no. 2.

Nwachukwu, J. C. \& Shitta, O. (2015). Testing the weak-form efficiency of stock markets. International Journal of Emerging Markets, 10(3), 409 - 426.

Reinganum, M. R \& Shapiro, A. C. (1987). Taxes and Stock Return Seasonality: Evidence from The London Stock Exchange. Journal of Business, 60 (2), 89-104.

Rossi, M. \& Gunardi, A. (2018). Efficient Market Hypothesis and Stock Market Anomalies: Empirical Evidence in Four European Countries. Global Business and Economics Review, 18(5), 604-617.

Seyyed, F. J., Abraham, A. \& Al-Hajj, M. (2005). Seasonality in stock returns and volatility: The Ramadan effect. Research in International Business and Finance, 19 (3), 374-383.

Tandelilin, Eduardus. (2001). Analsis Investasi dan Manajemen Portofolio. Edisi Pertama. BPFE-Yogyakarta. Yogyakarta.

Weigerding, M. \& Hanke, M. (2018). Drivers of seasonal return patterns in German stocks. Business Research, Vol. 11, 173-196. 